\title{
Exposing the vectors
}

\author{
Mike Daube
}

- Additional supplemental material is published online only. To view, please visit the journal online (http://dx.doi. org/10.1136/tobaccocontrol2022-057258).

Health Sciences, Curtin University, Perth, Western Australia, Australia

Correspondence to Emeritus Professor Mike Daube, Health Sciences, Curtin University, Perth, WA 6102, Australia;

m.daube@curtin.edu.au

Received 11 January 2022

Accepted 12 January 2022

\section{Check for updates}

(C) Author(s) (or their employer(s)) 2022. No commercial re-use. See rights and permissions. Published by BMJ.

To cite: Daube M

Tob Control 2022;31:383.
Thirty years after the start of this journal, the tobacco control glass remains only half full. We have seen much progress. Millions of deaths have been averted. But smoking still causes more than 8 million deaths each year.

Reasons for this continuing toll range from inadequate focus on prevention to complacency, but one cause stands high above the rest- the tobacco industry's ruthless determination to sell as many of its products as possible.

As pressure continues for further action, with growing calls for a timeline to end commercial tobacco sales, we should continue to expose, oppose and constrain the industry's activities. But history tells us that this will be a lengthy, bitterly fought process.

So what else may change the behaviour of the vector?

We criticise the companies and their spokespeople-but the key decision-makers escape largely unnoticed and unscathed. It is surely time to bring tobacco company board members more directly into the public arena, and confront them with the personal responsibility they share and bear for millions of deaths.

Writing recently about gambling, the Lancet's editor, Richard Horton, commented on 'the utter evil of an industry that does indeed prey on those facing social peril and financial precarity ${ }^{1}$ language surely also applicable to those who knowingly oversee the sale and promotion of products that kill half of their regular consumers.

So while tobacco companies spend billions on advertising, public relations, lobbying and front groups, it is time to bring their leaders out of the shadows, and call out their own evil behaviour as exactly that.

Experience shows that personalising the problem makes a difference. Even in the early 1970s, after my first foray into challenging boards by asking difficult questions at their Annual General Meetings in the UK, the chairman of Rothmans offered me generous funding to work on any campaign other than tobacco. Similarly, when Gallaher's leaders wanted to meet with us, we agreed-conditional on this following a ward round with the Action on Smoking and Health (ASH) honorary secretary,
Dr Keith Ball. They couldn't stay far enough away from the patients, couldn't get away fast enough and never sought to repeat the experience. Nowadays, the companies' own reports reveal that they find difficulty in attracting high-quality executives, ${ }^{2}$ and Tobacco Free Portfolios has shown that many investors are keen to avoid associating with Big Tobacco. $^{3}$

Focusing on the people who call the industry tunes will not solve all our problems overnight, especially as the companies get ever more creative in their marketing-while continuing to focus relentlessly on maintaining and increasing sales of their 'core product'. ${ }^{4}$ And of course, we should continue to press for evidence-based comprehensive approaches. But shining a light on the companies' boards will help identify the true vectors; it will cause well-earned discomfort for the people whose decisions cause so much harm; it will counter the tobacco industry's new charm offensives; and it will provide yet further rationale for young people and others to steer clear of this evil industry's products.

Funding The authors have not declared a specific grant for this research from any funding agency in the public, commercial or not-for-profit sectors.

Competing interests None declared.

Patient consent for publication Not required.

Ethics approval This study does not involve human participants.

Provenance and peer review Commissioned; internally peer reviewed.

ORCID iD

Mike Daube http://orcid.org/0000-0002-3479-2785

\section{REFERENCES}

1 Horton R. Offline: gambling — "we are everywhere, we see everything". The Lancet 2019;394:2214.

2 Daube M, Chapman S. The problem with selling a lethal product: you just can't get the staff, 2016. The guardian. Available: https://www. theguardian.com/commentisfree/2016/jul/13/the-problem-withselling-a-lethal-product-you-just-cant-get-the-staff [Accessed 11 Jan 2022].

3 Tobacco free portfolios. Available: https://tobaccofreeportfolios.org/ [Accessed 11 Jan 2022].

4 Philip Morris USA. Making our cigarettes. Available: https://www. philipmorrisusa.com/products/making-our-cigarettes [Accessed 11 Jan 2022]. 